\title{
Research on the Development Strategy of Travel Agency Under the Environment of Market Transformation
}

\author{
Guangming Yang \\ Kunming University \\ Kunming, China
}

\begin{abstract}
With the rapid development and continuous improvement of China's socialist market economy, the competition in China's travel agency market is becoming increasingly fierce, and the travel agency market is in a fierce environment for change. This paper analyzes the development status of travel agencies in the market transformation environment, and proposes the development trend and development strategy of travel agencies.
\end{abstract}

Keywords-travel agency; market transformation; development strategy

\section{INTRODUCTION}

China's travel agency industry has developed rapidly since the reform and opening up. With the development of China's socialist market economy, China's travel agency industry has undergone tremendous changes. Since China's accession to the WTO, the competition in the travel agency industry has become increasingly fierce, especially in the face of foreign travel agencies entering the Chinese tourism market. The travel agency industry generally feels that its operating efficiency is low and it lacks the competitiveness. The travel agency industry is facing severe challenges in market reform. However, opportunities and challenges coexist, and there will be more variables in the development of the travel agency industry in the future. To survive and develop, it is necessary to constantly study the market environment and find a path suitable for the development of travel agencies.

\section{ANALYSIS ON THE DEVELOPMENT STATUS OF TRAVEL AGENCIES}

According to statistics, the number of Chinese tourists was 5.539 billion in 2018 , an increase of $10.8 \%$ over the same period of the previous year; the number of inbound tourists was 141.2 million, an increase of $1.2 \%$ over the same period of the previous year; the number of outbound tourists was 149.72 million, an increase of $14.7 \%$ over the same period of the previous year; the total tourism revenue for the year was 5.97 trillion yuan, a year-on-year increase of $10.5 \%$.

As shown in "Fig. 1", from 2011 to 2017, the number of travel agencies increased from 23,690 to 27,939 , showing a continuous growth trend, but the overall growth rate is declining.

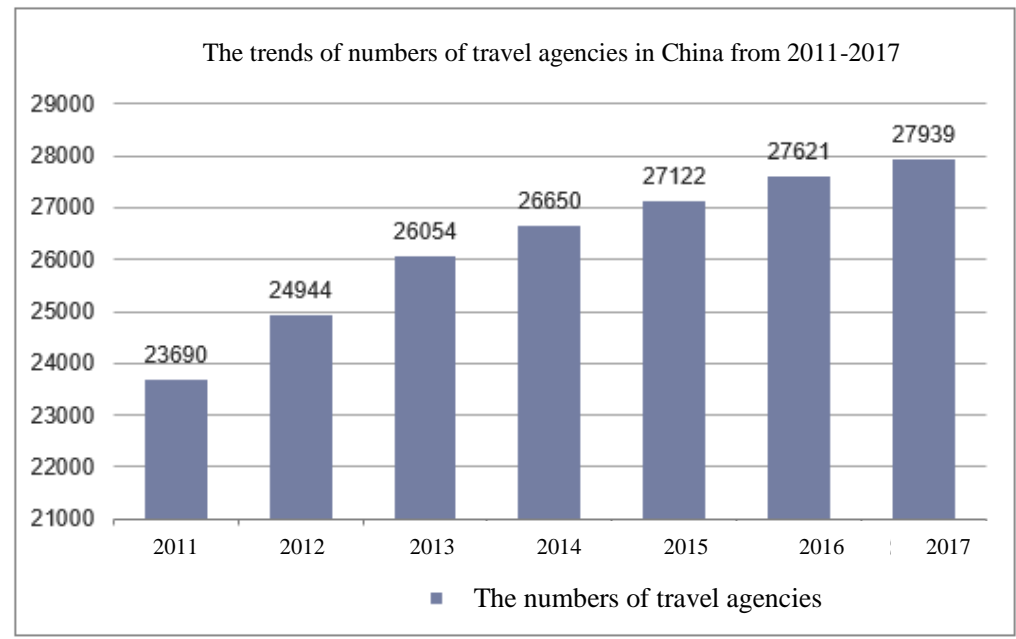

Fig. 1. The trends of numbers of travel agencies in China from 2011-2017. 
The data shown in "Fig. 2" indicates that the operating income of various travel agencies in China has increased

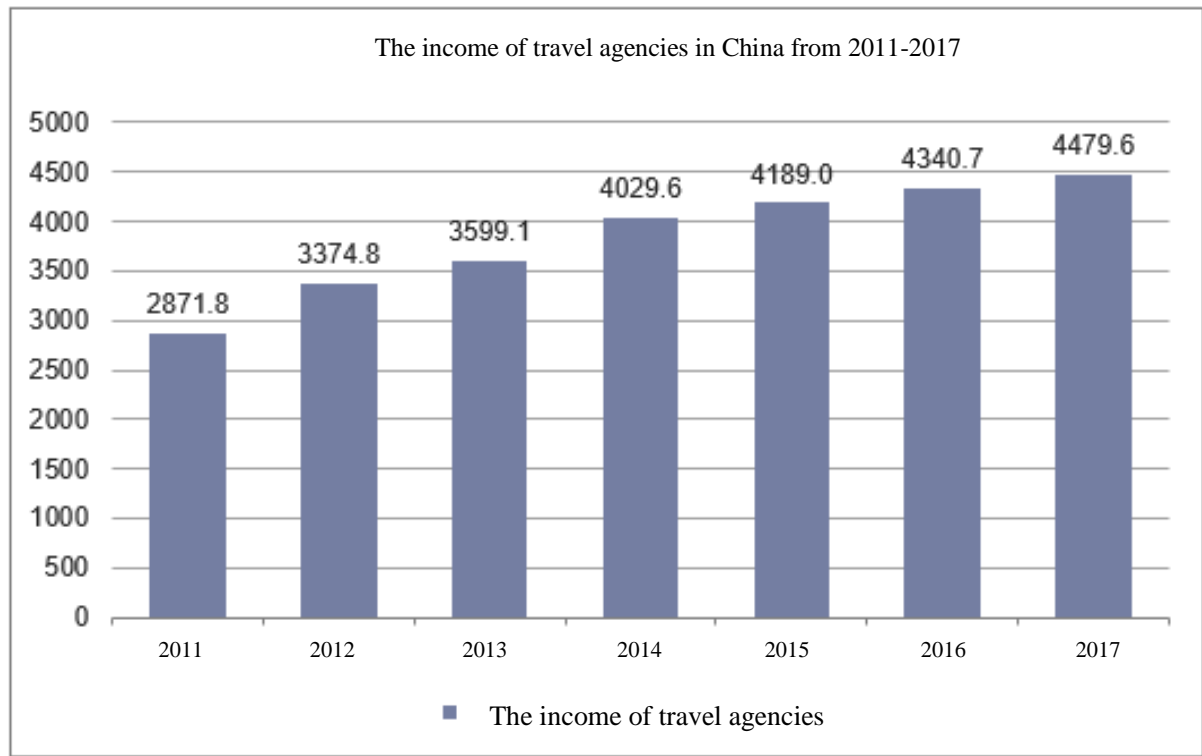

Fig. 2. The income of travel agencies in China from 2011-2017.

However, while the scale of the travel agency industry has expanded and operating income has increased, the industry's net profit margin has decreased. On the one hand, the entry barriers of Chinese travel agencies are relatively low, and the increase in national tourism demand has stimulated the rapid expansion of Chinese travel agencies and the increase in the overall operating income of the industry. On the other hand, due to the lack of innovative design capabilities of tourism products, similar travel agencies mainly obtain customers relying on the price, which leads to a decline in the industry's profit margins and a decrease in new entrants.

From the point of view of the industry division of labor system, China's travel agency industry is still in a transitional phase from horizontal division of labor to vertical division of labor and horizontal division of labor. In the early stage of industry development, China's travel agencies have adopted the classification standards of first-level, second-level and third-level agencies and Chinese and international agencies. With the promulgation of the "Travel Agency Regulations", the horizontal division of labor system has been weakened. Some large travel agencies have realized the importance of vertical division of labor. However, the entire industry has not yet formed a vertical division of labor, and the industry is facing transformation and upgrading.

From the perspective of market structure, China's travel agency industry has shown a trend from policy monopoly to market concentration. The market structure of China's travel agencies has gone through a process from policy oligopoly to monopolistic competition to full competition. Industry concentration shows a trend of high first and then low. a. Source: National Bureau of Statistics

\section{ThE DEVELOPMENT TREND OF TRAVEL AGENCIES}

\section{A. Intense Market Competition}

Since the reform and opening up, the number of travel agencies in China has grown rapidly. However, with the continuous growth of the number of travel agencies, competition in the industry has become increasingly fierce, and the trend of blindly forcing prices down has intensified. In order to compete for customers, some travel agencies will further profit from the low-priced tourism products, resulting in lower service quality and standards, harming the interests of tourists, and thus affecting the healthy development of the entire industry. In addition, due to the increasing internationalization of the travel agency industry, Chinese travel agencies are more competitive from the international market.

\section{B. Intensified Talent Competition}

Compared with other industries, travel agencies are a high-intensity, highly-related, and complex service industry. The travel agency industry is a human- and knowledgeintensive service industry. Its investment is mainly human resources, and its output is mainly services. Manpower and talents are the largest and most important capital of travel agencies. Therefore, the travel agency industry needs professional talent management and operations.

Due to the localization characteristics of tourism resources and tourism products, after foreign travel agencies entering the Chinese tourism market, it must inevitably consider the localization of business operations from the need to reduce labor costs, so as to seek long-term and stable development. The looting of talents, especially high-end talents with rich experience and familiarity with China's 
national conditions, will be the most convenient way for foreign travel agencies to enter the Chinese market. In addition, after years of development in China's travel agency industry, the number of travel agencies is increasing, and the competition for talents in the industry is increasingly fierce.

\section{Marketing Network}

With the popularization of the Internet, the development of $5 \mathrm{G}$ technology, and the development of visual terminal equipment, customers' consumption habits are gradually changing. More and more customers are accustomed to obtaining travel information through the Internet, and making convenient online booking and mobile terminal online booking. It is expected that the proportion of online tourism in the overall tourism industry will be further expanded.

As a new type of service, tourism e-commerce is an inevitable outcome adapting to the development of the market, and it is the core competitiveness of future tourism enterprises. Tour operators need to provide more diversified booking services by building an open e-commerce system and service platform to provide diversified products and onestop full-service services for target users. In line with the changes in user needs, vigorously developing e-commerce platforms, providing high-efficiency and high-quality services from information flow to capital flow for the target group is an inevitable trend of industry development.

\section{Wholesale and Retail Integration Trends}

Judging from the current development of foreign travel agencies, many large travel agencies and travel groups both adopt the operation mode of wholesale and retail, starting from wholesale, or starting from retail. After having strong product development and operation capabilities, they will increase their investment, establish a wide range of sales channels, and emphasize the combination of production, promotion and service of products with the construction of their own channels or distribution channels to form a business model of wholesale and retail integration. The integration of wholesale and retail is an effective way to enlarge and strengthen travel agencies, and meet the needs of the development of the outbound travel market.

\section{ThE TRAVEl AgENCY'S STRATEGY TO RESPOND TO MARKET TRANSFORMATION}

For travel agencies, the change of market competition is a change in the macro environment, not the travel agency can control. Travel agencies can take the initiative in a fiercely competitive market if they actively adjust themselves and adapt to changes in the competitive environment.

\section{A. Adhering to the Path of Grouping and Network Management, and Constantly Making the Development and Growth}

For a long time, the overall situation of China's travel agencies is low degree of grouping, small scale of single operation, low-level competition, and homogenization of products, short industrial chain and lack of core competitiveness. Taking the road of large-scale and group development and changing the industry's internal consumption as a community of interests are the strategic choices of China's travel agency industry. Taking the big travel agency as the core, the assets as the link, brand output as the feature, and setting up the travel agency enterprise group with the goal of large-scale and networked operation, will become the main mode of the group operation of China's travel agencies. The emergence of the travel agency group will greatly enhance the concentration of the industry and improve the international competitiveness of China's travel agency industry.

China's travel agency industry began to establish enterprise groups in the late 1990s, mainly achieving group management through vertical integration with the help of government guidance and human will. Practice has proved that this travel agency group cannot solve the deep-seated contradictions in the development of China's travel agency industry. At present, the entire travel agency industry is in a period of rapid expansion, and the market structure has developed from a monopoly of a few state-owned large agencies to a state of complete competition. The tourism hotel industry, scenic spots industry, tourism transportation industry and other industries also have similar excessive competition. Therefore, the upstream and downstream industries of the tourism industry basically belong to a completely competitive market structure. They do not have the premise of the vertical integration of the American economist Spengler's dual marginalization theory (when there is a bilateral monopoly between upstream and downstream enterprises, it can increase industry profits and lower the purchase price of consumers through vertical integration). It is also inconsistent with the vertical integration conditions advocated by Ronald Coase's transaction cost theory (upstream and downstream enterprises have specific assets of ex post facto bilateral monopoly). Therefore, vertical integration is at least not the choice of China's travel agency industry to form a business group. Taking the road of horizontal integration, that is, tourism enterprises form a multi-site enterprise group through mergers, joint ventures or investment in setting up new business units. First, developing economies of scale and network operations within the industry to form a tourism wholesaler, the division of labor system of tourism retail agents, and then developing industrial chain management have become the preferred choice for travel agency grouping. The specific mode of grouping through horizontal integration has four forms in practice, namely, administrative combination mode, capital operation mode, asset management mode, and management mode of special permission, all of which have successful examples. Travel agencies seeking to expand should choose their own grouping model based on their own development strategy, strength and brand. 


\section{B. Adhering to the Road of "Brand Winning", Cultivating Loyal Customers and Continuously Expanding Market Share}

After more than 40 years of development, China's tourism market development and industrial organization have made great progress, and the era of brand winning is coming. However, compared with other industries, the China's tourism brand awareness is relatively late, and brand building is far from the requirements of the market and people's expectations. Nurturing the high profits, competitive advantages and the possibility of product category expansion of famous brands make the brand become the universal pursuit of mature enterprises, and the brand strategy has become an important competitive means for mature industries. In the well-developed travel agency market, relying solely on the product is not enough to sustain the survival and development of travel agencies. Only by continuously developing new customers and maintaining old customers, travel agencies can achieve sustainable development, which is the ultimate goal of the management of travel agencies.

Years of brutal price competition have made many travel agencies in China deeply aware that price wars hurt others. Branding and network operation have become the natural choice to enhance the level of competition and the competitiveness. American marketing expert Larry Wright commented on the role of the brand, "Owning a market is more important than owning a factory, and the only way to own a market is to have a dominant brand."

At present, the outstanding problems in the brand management of travel agencies in China are mainly reflected in: brand awareness has not become the mainstream consciousness of the whole industry; there is no systematic research on brand management, and there is no scientific and reasonable brand building plan; the key points of brand management are unknown, and travel agencies should focus on building enterprise brands rather than product brands; brand concentration is low, and brand management can't keep up after brand expansion. Taking the brand road should be a development strategy that is correct and should be adhered to for a long time. However, the process of brand building, kernel filling, promotion, and maintenance and upgrading is a long and arduous process. It requires the government and enterprises to be down-to-earth, make the development step by step, which can't be short-sighted, impetuous and opportunistic.

On a macro level, the government and industry authorities should focus on regulating the market, establish rules and regulations, guide the competition behavior of travel agencies, accelerate the pace and intensity of the reform of the travel agency system, encourage mergers and acquisitions, and create easing policy, law and market environment for the expansion of excellent brands, in which the government can make a difference. As far as the micro level is concerned, travel agencies can only create excellent brands based on the development quality that focuses on profits and the operation that is more important than scale. In the hearts of tourists, excellent brands represent quality services, and for this, they are willing to pay a premium. For producers, good brands help them differentiate between different products, help them with product introductions and promotions, help them nurture repeat customers and build customer loyalty on this basis. In the process of creating excellent brands, in addition to overcoming the abovementioned outstanding problems, travel agencies are more important to maintain a good business mentality and put quality pursuits first, so as not to pursue short-term effects, but to focus on the long-term benefits of the business and brand building.

\section{Firmly Following the Path of Transnational Operations, Extending the Industrial Chain and Enhancing International Competitiveness}

Travel agencies in developed countries increasingly abandon indirect distribution channel strategies and instead adopt direct marketing strategies to acquire their own distribution networks by acquiring travel agencies in their source or joint ventures. The purpose is to reduce or even eliminate the intermediate links between travel agencies and tourists in tourist destinations, and reduce costs in order to attract more tourists.

In the cross-border mergers and acquisitions activities of the travel agency industry, the first and foremost acquisition targets are travel agencies in countries and regions with high travel and travel rates, and the purchasers are mainly travel agencies or travel agency groups in developed countries such as the United States, the United Kingdom, and Germany. Transnational operations have become an important trend in the development of the travel agency industry. To realize the sustainable development of China's tourism industry and break through the restrictions of international capital on China's tourism industry, China's tourism enterprises must also achieve transnational operations.

After decades of development, a number of strong national brand travel agencies have emerged in China, such as the CITS, the CYTS, the Kanghui Tourism Group, and the Shanghai Spring and Autumn International Travel Service. After years of planning and layout, these travel agencies have formed their own distribution systems in China, achieving network and group operations. They should take the lead in going abroad and setting up overseas branches through establishment and acquisition. First, they will realize direct overseas marketing, establish an overseas reception system, strengthen control over customer sources and profits, and form an interwoven pattern with an international tourism capital. Then it extends to the upstream of the tourist reception and enters foreign hotels, passenger transportation and other departments to form a complete industrial chain of inbound and outbound tourism.

\section{CONCLUSION}

Since China's accession to the WTO, the market environment of the travel agency industry has undergone tremendous changes. In this era of "competition", if travel agencies who are organizers of the tourism market want to stand out in the fierce market competition, they should 
constantly review the situation, adjust their strategic positioning, enhance their business strength, shape their own corporate brand, and practice good service, find the development path, seize the opportunities in the market transformation environment, and gain competitive advantage.

\section{REFERENCES}

[1] Sun Chenchen. Research on China's Travel Agency Industry Based on SCP Analysis Framework [J]. China Management Informationization, 2018(23):136-138. (in Chinese)

[2] Chen Hao. Research on the Management Strategy of Travel Agency for the Smart Tourism Market [J]. Tourism Overview (the second half of the month), 2018 (3): 41-42. (in Chinese)

[3] Dai Xuefeng, Pang Shiming. Is China's travel agency industry still "small and weak"? - Re-discussion on the industrial organization structure and performance of China's travel agency industry $[\mathrm{J}]$. Tourism Tribune, 2018(11): 48-55. (in Chinese)

[4] Ding Zongsheng. Discussion on Strategies of Travel Agency to Deal with Market Competition Reform [J]. Market Modernization, 2007(02): 51-52. (in Chinese)

[5] Kong Lingyi. Research on the Development Strategy of Traditional Large-scale Travel Agency in the New Situation - Taking China National Travel Service Baoding International Travel Agency as an Example [J]. China Economic \& Trade Herald, 2014(17). (in Chinese)

[6] He Jun. Analysis on the establishment of the vertical division of labor system in the travel agency industry [J]. Market Modernization, 2007 (29): 259-260. (in Chinese)

[7] Ministry of Culture and Tourism of the People's Republic of China. Statistical Bulletin of Culture and Tourism Development in 2018 [EB/OL], 2019-05-30/2019-06-03. (in Chinese) 